I Campinas State University (Unicamp), Department of Sociology,

Campinas, SP, Brazil

mridenti@g.unicamp.br

Marcelo Ridenti'

\title{
THE JOURNAL CADERNOS BRASILEIROS AND THE CONGRESS FOR CULTURAL FREEDOM, 1959-1970'
}

The journal Cadernos Brasileiros was the main Brazilian expression of a prominent international intellectual movement, the Congress for Cultural Freedom (CCF), founded in I950 in Europe in response to the World Peace Council, the latter inspired by the Soviets. ${ }^{2}$ A significant international and artistic network was created by the CCF through its funding of expositions, conferences, awards and, especially, its set of journals, seeking to express the particularities of the world of culture and the arts, but also the fight against political interferences that stunted creative freedom, especially in communist countries. The congress had offices in 35 countries and sponsored more than 20 periodicals, according to Saunders (2008: I3). The latter included Preuves (France, created in I95I), Encounter (United Kingdom, I953), Der Monat (Germany, established earlier, in I948, as a product of the Marshall Plan), Tempo Presente (Italy, I956), Quadrant (Australia, 1956), Cuadernos (Latin America, I953), and Cadernos Brasileiros (Brazil, I959). The headquarters of the CCF's International Secretariat was located in Paris, where the work of intellectual organization of its journals was centralized. ${ }^{3}$

The first issue of Cadernos Brasileiros had a print run of one thousand five hundred copies in I959. It was published quarterly and subsequently bimonthly from I963 onward. A report presented to the CCF tells us that three thousand copies of issue 6 of Cadernos Brasileiros (November-December 1963) were printed. By 1966 the journal was printing as many as five thousand copies 
per issue, distributed nationally, but concentrated especially in Rio de Janeiro city, then Guanabara state, according to data from the CCF's archives. ${ }^{4}$

In total, 62 issues were published up to the closure of the journal in September-October 1970 . Hence it circulated without interruption from the end of the Kubitscheck government until the beginning of the Médici government, traversing diverse political conjunctures expressed in the directions taken by the periodical. Approximately I7 articles were published per issue in $23.5 \mathrm{~cm} \mathrm{x}$ I $7.5 \mathrm{~cm}$ format. The journal had Ioo pages on average, each article about six pages in length with two columns of text, including essays $(48.3 \%$ of the total number of pages), studies (I7.I\%), book reviews (13.7\%), fiction (9.4\%) and other (I I.6\%), according to data compiled by Kristine Vanden Berghe (I997).

This article presents a brief reconstruction of the history of Cadernos Brasileiros, looking to comprehend its complex relation with the CCF, simultaneously one of dependency and relative autonomy. Six key moments are proposed for the analysis of this relationship: 1 . the foundation of the periodical in I959; 2. the intervention of the CCF in the journal in $1962 ; 3$. the reactions to the 1964 military coup in Brazil; 4 . the debate on militarism, with an opening to the left; 5. the response to the denunciations of links to the Central Intelligence Agency (CIA); 6. the closure of the publication in I970.

\section{THE MOMENT OF FOUNDATION}

The creation of Cadernos Brasileiros itself reflected close relations with the international congress, since the periodical emerged from a professional initiative by the CCF, which sent Julian Gorkin to Brazil, a Spanish journalist who had fought in the country's civil war and had been one of the principal leaders of the Workers' Party of Marxist Unification (Partido Obrero de Unificación Marxista: POUM), an organization known to be hostile to the Stalinists. Gorkin was responsible for Latin America in the Congress and from I953 to I963 was editor of Cuadernos, the entity's periodical specializing in Latin America, published in Paris. His work was decisive to the creation of the Brazilian Association of the Congress for Cultural Freedom and Cadernos Brasileiros.

The Association was founded in Rio de Janeiro on April I I ${ }^{\text {th }}$, I958. Present were 42 intellectuals, as reported in the first issue of Cadernos Brasileiros, AprilJune I959. Among them were renowned writers like Manuel Bandeira, João Guimarães Rosa, Érico Veríssimo and Cecília Meireles; journalists of the calibre of Luiz Alberto Bahia, Carlos Castello Branco, Prudente de Morais Neto and Franklin de Oliveira, as well as Alceu Amoroso Lima, Eduardo Portella and others, attesting to the prestige of the CCF, though its Brazilian publication did not necessarily inherit the same support, as can be concluded from the fact that 20 of the founders never collaborated with articles, as Berghe (I997: 55) observed.

The journal was inaugurated soon after the I959 Cuban revolution, which led Latin America to occupy a prominent place in the Cold War disputes. Gorkin 
contracted the intellectuals who launched the publication of Cadernos Brasileiros and who were also responsible for the Association: the literary critic Afrânio Coutinho - who had earlier published the Portuguese version of the US publication Reader's Digest - and the exiled Romanian Stefan Baciu, a journalist and surrealist writer who later became established as an academic in the United States. Both reported on their activities to the CCF's command in Paris, including letters and other documents. The entity continued to sponsor the periodical throughout its existence.

No agenda was set by the CCF, which allowed its directors the autonomy to choose the articles to translate from among those published in other journals in the network, granting substantial space to national authors. The latter, in turn, had the opportunity to have their articles translated and published in journals abroad, though this was not frequent. The relation between the directors in Paris and those responsible in Rio de Janeiro was negotiated in letters, from the salary of the directors and staff to the journal's content. A kind of reciprocity existed: the Brazilian periodical would publish articles important to the CCF and would disseminate its ideology, in exchange receiving space for Brazilian intellectuals to express themselves, not only the directors employed in a professional capacity, but also occasional collaborators whose articles were remunerated, a practice uncommon at the time. Initially most articles were specifically focused on cultural topics, with space too for those writing against the communists, accused of limiting cultural freedom.

An advisory board of leading authors oversaw the first issues of Cadernos Brasileiros. The board comprised I4 members: Adonias Filho, Anísio Teixeira, Cassiano Ricardo, Celso Cunha, Eduardo Portella, Elmano Cardim, Érico Veríssimo, Eugênio Gomes, Evaristo de Moraes Filho, Gilberto Freyre, José Garrido Torres, Levi Carneiro, Manoel Bandeira and Mário Pedrosa. Around half came from Bahia, now settled in Rio de Janeiro, which suggests that they were friends of fellow Bahian, Afrânio Coutinho, the journal's main articulator in artistic and intellectual spheres, while Baciu was responsible for day-to-day editorial work. All of them were involved in the literary world, four already belonged to the Brazilian Academy of Letters (ABL) and another four would later become 'immortals.'5 Just some of the board's members collaborated actively with Cadernos Brasileiros with varying degrees of involvement. Poems by Manuel Bandeira were published throughout the journal's existence, for example, but he was not very close, as Vicente Barretto - the editor after the arrival of Keith Botsford - admitted in a recent interview. Mário Pedrosa, by contrast, "took an active part in the seminars, the guy was always present." ${ }^{6}$ However, the fact that I4 members were willing to lend their names to boost the periodical's prestige shows that there was intellectual space for a publication of this kind, likewise that the ideology of the CCF had adherents. The symbolic rather than effective input of the board meant that it played no role in the issues from I963 onward. 
Cadernos Brasileiros was its most dependent on foreign input during this founding period under the direction of Stefan Baciu, as can be ascertained from the origin of the articles, $40 \%$, or slightly more, of which from I 960 to I 962 were by foreign authors. This was also the most anti-communist phase with publishing space given to prestigious international authors - like Raymond Aron, Ignazio Silone and Karl Jaspers - and national authors, such as the economist José Garrido Torres and military officers, specialists in geopolitics, Golbery do Couto e Silva and Carlos Meira Mattos. The three would become renowned architects of the I964 coup.

\section{THE MOMENT OF THE INTERVENTION OF CONGRESS IN CADERNOS BRASILEIROS}

At the start of the I960s, the CCF's command in Paris noted the limited influence of its publications in Latin America. These were marked by a particular anticommunist flavour of the I950s, linked to denunciations of what had been happening in the USSR and neighbouring countries, a distant reality for highly unequal societies with unstable democracies and striving to break from underdevelopment, like those of Latin America. This led to its relatively low intellectual prestige throughout the region, where national developmenalist, antiimperialist and communist ideas enjoyed considerable uptake. Intervention was needed to change the scenario, identifying the journals more clearly with the ideas of creative freedom and with economic and cultural development, attracting more intellectuals from the non-communist left. To this end, as diplomatically as possible to avoid alienating followers, the CCF closed the Mexican Examen in 1963 and, that same year, removed Gorkin from the directorate of Cuadernos, which would fold in I965, the CCF's support having switched to Mundo Nuevo, directed by the Uruguayan Emir Rodríguez Monegal (cf. Iber, 2015: 359).

The Brazilian section played a pioneering role in the change, receiving an intervenor from the CCF, the writer and editor Keith Botsford, who was in Rio de Janeiro from the beginning of I962, and would only leave the country in mid1963 in order to intervene in Mexico. Nicolas Nabokov, secretary-general of the CCF's Executive Committee, initially accompanied Botsford to Brazil (Iber, 20I5: 328). They sought to give Cadernos Brasileiros a more open international outlook, a change that would only properly take root from I964, after the coup d'état, since the traditional anti-communism remained in the context of the Goulart government, particularly in the period during which José Garrido Torres formed part of the journal's management. Torres was a leading figure at the Economic and Social Research Institute (Instituto de Pesquisas Econômicas e Sociais: IPES), an institution financed by the business sector, which prepared the terrain in the civil sphere for the ig64 coup.

In order to reform the periodical, it was necessary to remove its editor, Stefan Baciu, a journalist renowned for his anti-communist stance, who had 
worked since I953 at the Tribuna da Imprensa, a daily newspaper owned by Carlos Lacerda, where Baciu was foreign policy editor, and was so acclimatized to the country that he had become a naturalized Brazilian. On I ${ }^{\text {th }}$ August 1962 , Baciu sent a short message to Nabokov, forwarding a copy of his long letter of resignation, originally sent to Afrânio Coutinho, setting out the reasons for his decision to quit along with his wife, who also worked at the journal as an administrative secretary. ${ }^{7}$ He expressed his resentment: "we are sure to recover these nine years that we have given to the Congress for Cultural Freedom, nine years of youth, enthusiasm and complete selfless dedication." As well as the disappointment at losing the hard work of so many years, the words make clear his connection to the CCF since I953, four years after his arrival in Brazil, where he had obtained asylum as a fugitive from communism, long before the creation of Cadernos Brasileiros, testifying to the fact that a local network based around the CCF had been slowly consolidating throughout the decade.

Baciu's resignation letter to Afrânio Coutinho was translated by himself into French, revealing his desire for it to be comprehended too by the CCF's directorate. As well as Nabokov, a copy was also sent to John Hunt, the CCF's administrative secretary. ${ }^{8}$ He explained the reason for his resignation as the "negative and provocative action taken by Keith Botsford," seen by him as a political commissar under the command of the CCF. His position was contrary to the "opening to the left" advocated by Botsford, opposing any approximation with the Higher Institute of Brazilian Studies (Instituto Superior de Estudos Brasileiros: ISEB) or collaboration with intellectuals like Celso Furtado, Darcy Ribeiro and Candido Mendes de Almeida, who he named explicitly. His close affinity with Carlos Lacerda had come under threat from Botsford's directive, "neither Julião, nor Lacerda" - in other words, neither the Peasant Leagues nor the governor of Guanabara, neither the left nor the right, both taken as extremist.

Although in the letter he refers ironically to the accusation of being right-wing, Baciu's alignment with Lacerda was unequivocal. In another letter, he described even the well-known Catholic conservative Gustavo Corsão as a 'democrat,' as Cancelli (20I2: 8I) observes. He also considered Celso Furtado a 'communist' in a letter to Luis Mercier Vega, who had become the person responsible at the CCF for liaising with the directorate of Cadernos Brasileiros and other Latin American journals following the intervention of I962 (Iber, 20I5: 328). ${ }^{9}$ Like Gorkin, Mercier and other intellectuals organically linked to the CCF, Stefan Baciu was an intellectual originally from the left, whose persecution in Romania had led him to become anti-communist.

The revolt against Stalinist abuses, however, sometimes caused these initially left-wing agents to fear any kind of social transformation, however moderate, as though any kind of change would inevitably lead to what they perceived as communist totalitarianism. Rather than competing for leadership of the campaigns for change, therefore, which was what was expected of left- 
wing intellectuals, parties and movements, the fear of communism ended up prevailing for many, such as Baciu, to the point of opposing any attempt to develop closer relations with ISEB, Celso Furtado and other reformists who had international contacts with members of the CCF who were sympathetic to their reformism as an alternative to the revolutionary project emanating from Cuba.

However, Baciu's departure - replaced as editor by the aforementioned young law graduate Vicente Barretto ${ }^{\text {IO }}$ - did not immediately alter the journal's political orientation, though it became more open, as reflected in issue I5 (October-December I962), devoted to the question of Africa, with the participation of specialists from various streams of thought, such as Roger Bastide, Edison Carneiro, Manuel Diegues Júnior and José Honório Rodrigues. But the national setting evolved towards a political polarization under the Goulart administration, and - albeit discretely - the periodical leaned toward the side of the enemies of the federal government.

Baciu's exit and the appointment of Barretto in 1962 were a clear case of CCF intervention in Cadernos Brasileiros, including here the long-term presence of Botsford in Rio de Janeiro. Paradoxically, though, this outside interference sought to create more space and greater diversification in the local production, seeking to broaden the journal's readership and cultivate deeper roots in the artistic and intellectual spheres. The national contribution - which in I 962 was a little over $50 \%$ - rose to almost $80 \%$ in 1963 , almost $70 \%$ in 1964 , and remained consistently above $80 \%$ from 1965 onwards, as shown in the data compiled by Berghe (I997: 48). The most substantial broadening of the ideological umbrella of support for the journal, however, had to wait for a more suitable political context, which would only take place sometime after the I964 coup, when the forces that had supported it began to fall out among themselves.

\section{THE MOMENT OF THE 1964 COUP}

One surprising expression of the autonomy of Cadernos Brasileiros took place during the I964 coup. Though not made explicit in the pages of the periodical, which maintained the discourse of political neutrality in the name of objectivity, its directorate in fact supported the 'revolution' behind the scenes - to the extent that they adopted a uncommon stance: they challenged the orientation given by the CCF's international command. In the immediate post-coup period, the CCF had signalled its opposition to the military coup, since that its professed aim was to defend intellectual freedom and democracy, contrary to any kind of dictatorship. They feared a negative repercussion among the European public to any support from the CCF for a military coup that was being criticized by the press worldwide. Along these lines, John Hunt sent letters and telegrams to Afrânio Coutinho, offering all the entity's international backing to resist the arbitrary acts against intellectuals. He made it clear that "being anti-Goulart was not sufficient reason for the abuses committed against democratic proce- 
dures, and I think we should be brave enough to say so." II For Hunt, "Cadernos Brasileiros would gain many friends, inside and outside of Brazil," demonstrating "to those who have any doubts that you are as prepared to defend intellectual freedom in Brazil as in any other place." ${ }^{\text {2 }}$

But Hunt failed to convince Coutinho, who presented his arguments in various messages, such as a four-page letter that sought to present "a fair picture of the situation." He alleged distortion of the facts by the foreign press and pointed to popular support for the "revolution against Goulart." ${ }^{13}$ Barretto's response to the I964 events was the same as Coutinho's, judging by his correspondence at the time with Luis Mercier, who for his part identified with Hunt's more cautious position. Barretto wrote that "the revolution that deposed Mr. João Goulart seems to have ushered in a new era in the country." He criticized the equivocations of the international press agencies that "described the revolution as a 'coup d'état,' which amounted to diminishing and ignoring the revolutionary and popular character of the movement." ${ }^{\text {I4 }}$ For the editor of Cadernos Brasileiros, it had not been a coup but a revolution, one completely misunderstood abroad.

In his reply, Mercier declared that he was only "very partially" persuaded by the Brazilian's arguments, since the country's governance had been taken over by "a military regime, provisional undoubtedly, but whose duration depends on the armed forces themselves." ${ }^{15}$ Barretto responded that the military had been sensitive to the "growing popular unrest," leading to the overthrow of Goulart and the installation of a revolutionary government that would take "radical measures like the removal of politicians from office or a suspension of political rights." He expressed a degree of approval of these measures, arguing that the new government had limited its own power "juridically via the Institutional Act," which kept the I 946 constitution "in full force" with a few modifications, providing assurance that the presidential elections would be held in October I965. Disagreeing with Mercier, who argued that political control had fallen into the hands of the military, Barretto stated that "the installed regime is guaranteed by them as, indeed, the constitution stipulates - but does not depend on their will." To back up his assertion, he included with his letter Castelo Branco's inauguration speech and a lecture by Lincoln Gordon, US ambassador to Brazil, an active supporter of the military movement, as is wellknown. ${ }^{16}$ The Brazilian editor made explicit how he stood in that political context - a situation that would change, especially after the publication of Institutional Act n.2, October I965, which substantiated the fears of the CCF's Belgian anarchist, never persuaded by Barretto's arguments.

Despite the disagreements, Hunt's thoughts must have reverberated with Coutinho and those of Mercier influenced Barretto, judging by the brief editorial that the latter wrote for the first issue of Cadernos Brasileiros following the I964 coup. ${ }^{17}$ The text placed the Brazilians more closely in line with the inter- 
national directorate and received praise from Mercier: "the small editorial on the right to heresy is most timely." ${ }^{18}$ The letters exchanged with the foreign directors revealed the enthusiastic support of the national directors for the I 964 'revolution' soon after the coup. This support was never explicitly manifested in Cadernos Brasileiros, whose public image remained the one expressed in the editorial, which implicitly backed the I 964 movement but subtly warned against the potential persecution of intellectuals and the risk of the military remaining in power, thus to some extent combining the views of the Brazilian and foreign directors.

The editorial - a recourse seldom used in Cadernos Brasileiros, which was generally published without any declaration from its editors - allows us to affirm that, initially at least, the journal maintained something of an ambiguous relation with those in power. The text reveals that Cadernos Brasileiros supported the coup but also shows a degree of caution and apprehension over the directions that the movement was beginning to take. The editors assert that both hope and apprehension followed the "declarations of the main leaders of the revolutionary movement of March $3 \mathrm{I}^{\text {st. }}$. Hopes centred on the promised political, economic and social reforms, which "in a rational climate [...] unite Brazilian intellectuals." Apprehension stemmed from the danger of taking "simple ideology as subversion," affecting the intelligentsia through the seizure of books, imprisonments and the removal of intellectuals from public life without proof of any "subversive action." In other words, the editorial positioned itself against the police excesses of the regime, which curbed the freedom of intellectuals, and appealed to the new government to assure even the "right to heresy," a right that had been threatened by the Goulart government and needed to be guaranteed by the I 964 movement. The text then cites a speech by Castello Branco, where he averred that "the anti-communism of the revolution accepts 'that Brazil's political and social evolution should also incorporate ideas and proposals of the democratic left." The editorial considered the 'anti-communist character' of the 'revolution' to be a "consequence in fact of it being truly democratic," but observed that "the disquiet threatens to spread among the intellectual spheres." Indeed, the threat became real, as can be observed by the diffusion of the term 'cultural terrorism,' initially coined by the Catholic thinker Alceu Amoroso Lima in July I964, and soon adopted by the left as a whole (Czajka, 2009: 2I4).

The 'right to heresy' demanded by the editorial incorporated the influence of one of the main authors of the CCF, Sidney Hook, president of the Executive Committee of the American Congress for Cultural Freedom. In I953, the excommunist Hook published the book Heresy, Yes, Conspiracy, No. As the title of the work suggests, he argues that democratic order should allow the heresies of left-wing thought, even Marxist, since the free debate of ideas is indispensable to democracy, taking academic freedom as a basis for authority. What would be 
unacceptable, though, is the conspiring of the international communist movement, which works to destroy democracy. Hook proposed a liberal anti-communist struggle, critical of the primordial anti-communism that confused heresy with conspiracy - the case of the McCarthyism of the I950s in the United States - but also contrary to neutralism in the Cold War, since the supposedly progressive equidistance tolerated conspiracy as though it were heresy, underestimating communist subversion and soviet propaganda (cf. Gremion, I995: I33-I34). In the Cadernos Brasileiros editorial, published soon after the coup, a defence of heresy by the intelligentsia clearly appeared, but also the need to combat conspiracy in order to affirm Brazilian democracy.

The international command of the CCF had no problem subscribing to the editorial, closely in tune with its orientation, as demonstrated by the praise from Mercier cited earlier. But there were some revealing nuances. For example, there was at least one more case of resistance to adhering to the international orientation, when the CCF requested, in vain, support from Cadernos Brasileiros for Celso Furtado, persecuted after the coup. The rejection of Furtado by the journal's directors did not end with Baciu's dismissal. The sympathy of part of the international command of the CCF for the northeastern economist - after all, he was not a communist and could provide an alternative to the radical advance based on Cuba's example, as highlighted earlier - was not echoed by its national association. Furtado was from another intellectual network, a rival to Coutinho and his journal. Furthermore, his name might have constituted a threat to the group in control of the periodical, since it was evident that he had some influence in the CCF, so much so that even John Hunt - a proven CIA operative - interceded on behalf of him in various letters written after the coup, but was repelled by Afrânio Coutinho, as Iber (2015: 333-335) has already observed.

Thus, for example, Coutinho believed that Celso Furtado, "despite his high intellectual stature," and though not a communist, "was part of this radical program, allied with Goulart, Brizola and the communists." He implicitly rejected the request to defend Furtado, who, he said, was "free. He merely had his political rights suspended for ten years," the same punishment given to "hundreds of people, civilian and military, men engaged in anti-democratic activities." ${ }^{19}$ In reply, Hunt maintained a friendly tone, but insisted that the Brazilian should "remain attentive to international opinion on the punishment of people like Celso Furtado," which continued to have negative repercussions in the foreign press. ${ }^{20}$

Implicit was a concern that the CCF's ignoring of the abuses against intellectuals perpetrated by the post-I964 regime might have negative repercussions in the international cultural spheres supportive of the entity. Hunt's letter suggests that he was especially worried about the repercussions that the persecution of Furtado and other intellectuals could have abroad, more so perhaps than about the persecution per se. 
The initiative to conduct an investigation into the state of freedom in Brazilian education did not come from the journal and its Brazilian directors, but from John Hunt and sectors of the international CCF, such as the Committee for Science and Freedom. This inquiry documented various instances of persecution, dismissal and disfranchisement of university professors and other intellectuals, victims of various types of arbitrary power. The government responded that the CCF's report was part of a disinformation campaign. Patrick Iber used this example to argue that Coutinho had won the arm wrestle with Hunt: the CIA employee had been unable to persuade the Brazilian director to adopt a more liberal plan of action (Iber, 20I5: 334-335). But this divergence needs to be nuanced, given that soon afterward the editorial to Cadernos Brasileiros had underlined the need to defend the heresies of the intelligentsia, and important members of the CCF had visited the country and learnt about the viewpoints of its local supporters, leading to a convergence of their positions, as attested by the episode of the critique of militarism.

\section{THE MOMENT OF THE CRITIQUE OF MILITARISM AND THE OPENING TO THE LEFT}

Despite a certain difference evident in the correspondence, there was also an implicit pact: Cadernos Brasileiros reproduced the international ideology of the CCF, but ultimately possessed the autonomy to decide on how to adapt it to domestic issues. The journal negotiated and attempted to convince the international command of its positions, also making concessions, such as the publication of a dossier on the military that was suggested by the CCF, but only went ahead when domestic interests became more closely matched with the international interests. This dossier, published in the final issue of $1966,{ }^{21} \mathrm{ex}$ pressed the convergence with the headquarters in Paris, but ended up cooling relations between military sectors and the publication. According to Vicente Barretto, organizer of the dossier, he received a telephone call in protest from the Army general Golbery do Couto e Silva soon after the journal came out and after this the general never again entered into contact. ${ }^{22}$ Nonetheless, Cadernos Brasileiros was never censored by the official agencies.

The timid response of the military can be partly attributed to the fact that the dialogue of the journal's intellectuals with the regime remained open, even extending to collaboration, as attested by another letter from Barretto, informing Mercier that he was sending in attachment "the Cultural Plan of the Costa e Silva Government presented by a commission that includes our own Afrânio Coutinho and other collaborators of Cadernos Brasileiros." 23 The director Afrânio Coutinho, in particular, maintained good relations among the circles of power, so much so that he canvassed posts of intellectual prestige in the government. In a letter to Hunt in March 1967, for instance, he remarked that his name was on the list to join the Federal Council of Culture 
but had been cut by the president Castelo Branco. He attributed this exclusion to the impact of the Cadernos Brasileiros issue dedicated to the military issue, an idea probably mentioned to please the director of the CCF, since he took the opportunity to ask for funds to make contacts and visit Mexico from New York, where he was working as visiting professor at Columbia University. He commented that "fortunately, he (Castelo) is going to leave office on March I $5^{\text {th }}$, so let's hope things improve." ${ }^{24}$ In other words, he declared his distance from Castelo Branco and his hopes for the next government with which he had collaborated in the organization of its cultural plan.

"The militarist presence" was the title of Barretto's article that opened the dossier, straight after a short editorial by Afrânio Coutinho, in which he presented the journal issue as a result of the work of "a group of sociologists, researchers and historians that study the theme in its varied and complex aspects" (p. 2). As usual, the publication proposed contributing scientific neutrality to the debate, claiming to be above ideologies. The words of the organizer as he prepared material were along the same lines, seeking "to give such balance to the dossier that the government cannot say that the journal is subversive and, at the same time, it is not going to help the interests of the opposition." 25

Barretto's article observed that, from I955 to I966, thirteen countries in Latin America had experienced military intervention in their political governance. He goes on to explore the topic of militarism, referring to various historical periods, but focusing on events in Brazil (p. 3-7). Militarism was defined "politically as the dominance of the military in the Government; socially it involves the predominance of military criteria and values in a nation; culturally it emerges as the spirit and mental attitudes of the military, transferred to intellectual life" (p. 4). Barretto carefully cited a series of authors in order to highlight the risks of militarism, concluding that it could "collapse into turmoil, in terror" (p. 7). He was careful not to attack the Armed Forces, explaining that militarism was a "deformation of the military mentality," involving "the belief in a closed society, where social divergences and unrest are resolved by force" (p. 4). Perhaps for this reason, he did not explicitly mention the recently published Institutional Act n.2, which clearly set out the possibility of retaining the military in power, displeasing some of its civil allies, particularly those from the ruling classes.

The article met Hunt's expectation for a more critical stance in relation to the military, so much so that it was reproduced by Mundo Nuevo, which also published the article "The military opinion," by Mário Afonso Carneiro, in the same issue from I967, the latter originally written for the dossier in Cadernos Brasileiros. ${ }^{26}$ It was some reward since few articles by Brazilians gained any space in the international journals of the CCF network.

In this context, the concern of the CCF in Latin America was to ponder the question of development and the role of the elites - obviously not from an 
anti-systemic perspective, but in accordance with the theories of modernization then in vogue (cf. Ribeiro, 2006: 53-74). To this end, indeed, the CCF sponsored initiatives like a large event on elites and development in Latin America, held in Montevideo in I965, to which were invited numerous leading intellectuals from across the political spectrum. Various Brazilians were present, some of them living abroad to escape repression, like Darcy Ribeiro and Fernando Henrique Cardoso, authors respectively of the texts "The Latin American universities and social development" and "The industrial elite in Latin America." Although invited, Celso Furtado was unable to attend. ${ }^{27}$

The CCF also sought a broader cultural vision, especially in the pages of the journal Mundo Nuevo, highly regarded among the literati of the Latin America, which even published poems by the Chilean communist Pablo Neruda, one of the leading figures of the World Peace Council, once the archenemy of the CCF. The regional dispute was no longer centred as such on the communist parties and its intellectuals - generally speaking, advocates of peaceful coexistence between the superpowers and of national and democratic revolutions within the established order - but on armed left-wing groups, influenced primarily by the Cuban example.

Cadernos Brasileiros, for its part, finally consolidated the international directive of opening up the journal to more diverse points of view, including providing space for young artists, literary figures and social scientists, such as Francisco Alvim, Fábio Lucas, Wanderley Guilherme dos Santos, Octávio Guilherme Velho, Gilberto Velho, Moacyr Palmeira, Vilma Arêas, José Guilherme Merquior, Sérgio Paulo Rouanet, Nelson Mota and others, some of whom identified with left-wing positions. This approximation with the field of opposition to the dictatorship helps explain why the denunciations of CIA funding of the CCF had little impact on the Brazilian journal - after all, the moment of the denunciations practically overlapped the period when it began to open up to the left.

\section{THE MOMENT OF THE DENUNCIATIONS OF LINIS TO THE CIA}

The revelation of the CIA's secret support for the CCF and its journals - following reports in the New York Times and the Californian journal Ramparts in the mid-I960s - did not entail a loss of prestige for Cadernos Brasileiros among the intellectual spheres, including those of the left. Despite its relevance, Cadernos Brasileiros was relatively secondary in the intellectual setting before I964- when rival publications like Brasiliense stood out - and also after the coup, a period of wide divulgation and prestige for Revista Civilização Brasileira. Prevailing in this intellectual context was what Roberto Schwarz (I970) called a "relative cultural hegemony of the left," strong enough to pull into its orbit even publications initially more aligned with the right, such as Cadernos Brasileiros. Around I966, the journal was already in its own way part of the broader front of resist- 
ance to the dictatorship, providing increasing space for the collaboration of left-wing intellectuals, clearing the way even for new generations that had few options to publish - and in a professional way, receiving payment for the work.

There were no strong motives for condemning a relatively secondary journal, which at that time did not pose a threat to the predominance of the ideas of the intellectual left, rather it fell into its orbit. The publication revealed itself to be a moderate opponent of the military, albeit without directly confronting the regime and maintaining some dialogue with its members, at the same time that it remained plural and open to intellectuals considered progressive, whether established or beginning their careers, even employing Kátia Valladares in its editorial office, a woman who had lived in Cuba and possessed connections with the armed left. ${ }^{28}$ In a context in which the journal's explicit anti-communism had been left behind, though it maintained the liberal postulates of the CCF and its contacts with the military regime, there was no motive in Brazil to dwell on the denunciations concerning CIA funding, which, moreover, had been unknown to the editors and collaborators. Furthermore, the CCF's sponsorship during this period came from the Ford Foundation, and no longer from the CIA, which had withdrawn as the discovery of its activities loomed. It was in virtually nobody's interest to create problems for Cadernos Brasileiros and its collaborators.

Via the editorial "First and last declaration" (Cadernos Brasileiros n. 43, July-August, I967: 3-6), the journal responded to the accusations of CIA funding, albeit without citing them explicitly. It asserted its status as a Brazilian periodical, critical and independent, its freedom of action proven by the pioneering stances taken in relation to the question of Africa in 1963, the protest against persecution of intellectuals in 1964, and the problem of military power in I 966. It was open to intellectuals of any ideological persuasion and to young artists, maintaining total freedom as its slogan. The editorial explained that the journal had been published in collaboration with the Latin American Institute of International Relations (ILARI) ${ }^{29}$ since I966, an institution financed exclusively by the Ford Foundation, and cited a long excerpt from the declaration of ILARI's directorate, taking up more than half the editorial, reaffirming the autonomy of the institute and the journals that it sponsored at that time: Aportes, Mundo Nuevo and Cadernos Brasileiros. No mention was made of the CCF, nor the fact, by then well-established, that funding for the CCF and its publications had essentially come from the CIA and its front organizations, like Fairfield, until I966. In the cited excerpt, ILARI's directorate refers to the "inquisitors from the right and the left," who, however, had been almost entirely absent in Brazil. After release of the issue containing this editorial, the journal published texts by Florestan Fernandes, Edison Carneiro, Fernando Pedreira, Alceu Amoroso Lima (already in his left-wing Catholic phase), Abdias Nascimento, Fábio Lucas, José Leite Lopes and other intellectuals considered left-leaning. 
Although the US intelligence agency had been the main source of funding for the CCF and its journals until I966, these institutions had acted autonomously according to authors like Gremion (I985) and Coleman (I989). Saunders (2008), however, indicated the opposite: while she recognized that few CCF directors had been CIA agents, she considered that all of them knew something or suspected the agency's participation, such was the amount of evidence available. Iber (20II, 20I5), for his part, argues that the CIA participated but had been unable to control the complex network that it helped create: the CCF had been no mere "puppet of the USA" (Iber, 20 I : 263). Moreover, divergences were evident between its agents Josselson and Hunt, the latter supposedly more open and liberal.

The CIA's support was probably known by only a few collaborators to the CCF's journals, and protests even broke out when the story came to light. However, there is no reason to presume that the intellectuals were useful idiots. Both on the American side and the Soviet side, they participated in the dispute between the superpowers, despite being unaware of all the facts or all the rules of the game. They were used by the powers and their institutions, but they also used the latter to their own personal or collective benefit.

Raymond Aron's example is instructive here. He referred to the topic in his memoirs, where he claimed that he always wrote with complete freedom for the CCF's journals, and that the experience was fundamental in terms of influencing European intellectuals in the fight against Stalinism, as well as enabling him to work and exchange ideas with intellectuals like Josselson, Kennan, Polanyi and others. He considered that he and the majority of their peers would have more than likely refused to collaborate with the CCF had they known about the CIA funding, although he admitted that this attitude would have been fairly unreasonable. In his own way, he justified the secret nature of the support: "The CCF would have been unable to fulfil its task - and it fulfilled it - without the camouflage or, if you want, the lying by omission" (Aron, 20Io: 3 I 8 and ff).

Michael Josselson, the main director of the CCF from I950 to I967, along with his assistant John Hunt, were removed from office following the crisis generated by the denunciations of the links of both to the US intelligence agency. All the blame fell almost exclusively on the two of them. However the denunciation of the CIA's support affected the credibility of the CCF and its journals, which saw their ideology of intellectual independence shaken, so much so that the CCF changed name, becoming called the International Association for Cultural Freedom (IACF). Within a few years, these institutions had disappeared, victims of the loss of their prestige and credibility, as well as a drying up of funding. 


\section{THE FINAL MOMENT}

Cadernos Brasileiros continued to exist for some time while it still had the backing of the CCF - now renamed the IACF - which received funds from the Ford Foundation to continue the financing of its journals in Latin America. When this support ended in I970, the journal closed. The foundation switched its priorities and soon began to fund institutions like the Brazilian Centre of Analysis and Planning (CEBRAP), made up of intellectuals that the dictatorship had expelled from the University.

One episode clearly expressed the ambiguities of the periodical, particularly those of its director (and, for that matter, Brazilian liberalism in general), just when the crisis in funding worsened. In October I970 - the height of the Anos de Chumbo, the Years of Lead, under the Médici government - Afrânio Coutinho declined Mercier's invitation for him to remain as honorary president of the Brazilian Association for Cultural Freedom, but unremunerated. He replied that his name has been put forward as cultural attaché in Paris, a post to which he aspired. Were he to accept Mercier's invitation, he wrote, he would continue "to be seen by the authorities as the person responsible" for the Association and its journal, which would not be good for his ambitions. In this case - Coutinho wrote in the final sentence of the letter - he "would assume all the risks but none of the advantages" of working for the institution. ${ }^{30}$ Until the end, therefore, he sustained his ambiguous relationship to the government and the opposition, a stance typical of many liberals of the period, generally linked to the traditional middle classes (Saes, I984).

Whatever degree of editorial autonomy it possessed, Cadernos Brasileiros remained economically dependent on the foreign organization and was unable to set down enough local roots to continue its project. However, it did allow the circulation in Brazil of international debates disseminated by the head organization, including the active participation of local collaborators with a variety of outlooks, attempting to establish its own position in the intellectual field, balanced between the national and international cultural and political forces involved in diverse political configurations in the tumultuous I96os. Intellectuals were far from being puppets of the interests in play in these Cold War disputes, but were rather proactive subjects immersed in the day-to-day social struggles.

Though occupying a subaltern position in the international scenario and a secondary place in the Brazilian intellectual field, the journal conspicuously expressed the trajectory of certain liberal circles in diverse contexts, ranging from the explicit anti-communist positions widespread pre-I964 to the formulation of critiques of the military regime, even opening itself up to collaboration with young social scientists and others considered left-wing, though without losing the opportunities to adapt to those in power. 


\section{IN CONCLUSION}

The brief historical reconstruction and analysis of the relations between the CCF and the journal Cadernos Brasileiros - based on the correspondence between the institutions directors and other documents, on the journal's editorials and articles, on the interviews conducted and on the dialogue with the bibliography - allows some conclusions to be drawn. In general, a certain dependency existed in relation to the international organization, but with important expressions of relative autonomy.

At the time the journal was founded, in I959, important sectors of Brazil's artistic and intellectual sphere proved receptive to the foreign initiative as financer of the publication, in tune with the ideas of cultural freedom disseminated by the CCF. During this period, the pages of Cadernos Brasileiros were dominated by intellectuals who to some degree shared the CCF's anti-communism - a sentiment already somewhat outmoded in a Latin American context more receptive to the ideas of anti-imperialism and national development than to the imperative to fight Soviet communism. This was the most dependent phase of the journal, almost half of whose pages were taken up by reproduced foreign texts. Nonetheless, Brazilian authors assured their own space to the extent of maintaining a more conservative line than the international directive, resisting the opening to a new era of détente, a politics of peaceful coexistence between the superpowers. So much so that the journal became the target of outside intervention.

As we saw, having observed the low prestige of its journals in Latin America, as well as the advance of developmentalist ideologies, the CCF's international directorate decided to intervene in the region, beginning with Brazil in I962, attesting to the international power over its local agencies. Sent to Rio de Janeiro, the writer Keith Botsford presided over a reorganization of Cadernos Brasileiros, emphasizing the theme of creative freedom, along with economic and cultural development, seeking to attract non-communist left-wing intellectuals. In other words, the external intervention sought to breathe new life into the journal, providing an outlet for a diverse range of national authors. This shift in focus led to a substantial decline in the number of foreign texts published thereafter, becoming around a fifth of the total. However, the political turbulence prior to I964 delayed the proposal for a broader opening to diverse currents of thought. Despite the dismissal of the previous editor, the journal's political position continued to be more right-wing than the CCF's directors, a fact that became clear following the ig64 coup, treated as a revolution in the pages of the periodical.

The responses to the coup revealed frictions between the international and local directors, the latter more conservative, who knew how to assert their relative autonomy. The international directors expressed their concern about the repercussions on the foreign readership of any CCF support for a military 
coup that persecuted intellectuals. By contrast the local directors enthusiastically supported the I964 movement from the outset. This becomes clear by studying the correspondence between the two, although this also generated a kind of compromise between the directors of the institutions, so that local support for the coup - almost unconditional at first - was not made clearly explicit in the pages of Cadernos Brasileiros. The public image was still the one expressed in the post-coup editorial, which produced a kind of conciliatory synthesis of the debate evident in the letters, backing the I 964 movement but simultaneously warning against the potential persecution of intellectuals and the risk of the military staying in power.

The frictions between the local and international directors diminished for good following the journal's dossier on the military at the end of I 966 , when the national situation pointed to the continuation of the military government for an indefinite period, thwarting the interests of those liberal sectors with which the journal's directorate identified itself. Such was the case of the main civil leader of the coup, Carlos Lacerda, who broke away from the military in order to create the Frente Ampla (Broad Front) of opposition to the government in November 1966, the same month that Cadernos Brasileiros published the issue that displeased the military. As is well-known, Lacerda, the former governor of Guanabara, ended up having his political rights revoked after promulgation of Institutional Act n. 5, in December I968 - the year when the journal moved closer to the wider political and ideological spectrum of resistance to the dictatorship, yet even so was not censured by the official bodies. After all, its strength and penetration were limited and its director in particular, Afrânio Coutinho, still maintained good relations with the government.

The relative opening up to more left-wing positions - especially in I967 and I968, in line with the international directive to allow room for more diverse points of view - gave space not only to established authors, but especially to young critical intellectuals issuing from the universities, who were looking for outlets to divulge their research. In this context, though maintaining various points of contact with the government, the journal became situated within the wider spectrum critical of the military remaining in power, which helped prevent it from a loss of credibility following the denunciations of CIA funding to the CCF.

At national level, the trajectory of Cadernos Brasileiros can be interpreted as an expression of the ambiguous coexistence of liberals with both the dictatorship and the opposition to it, a result of the attraction exerted by emerging transformative worldviews - a certain "relative cultural left-wing hegemony," in the terms of Schwarz already cited - and, simultaneously, the attempt to change in order to compete for space in the intellectual field, reaffirming liberal or conservative positions. The latter attempted to incorporate, in their own way, the agenda of reforms for development (but in the universe of the elites) 
and the critique of militarism, even providing space in the journal for left-wing intellectuals, but seeking to direct the struggles to transform society in a direction controlled by the established order.

The relative shift to the left of Cadernos Brasileiros from I 966 did not entail the loss of contacts with the military, as demonstrated by the example of Afrânio Coutinho, the journal's main direction, who collaborated in the elaboration of the cultural plan of the Costa e Silva government, and never desisted from ambitions to occupy intellectual posts in the government.

Examined from a class perspective, the journal's itinerary reflected the relationship of the traditional middle classes to the political system in Brazil, in the sense analysed by Décio Saes (I984). They mobilized in favour of the I964 coup, opposed to so-called populism and the communists, but this did not necessarily imply support for the continuation of the military in power. After the moment of the 1964 crisis passed, eliminating what they saw as the dangers of populism and communism, sectors of the so-called middle classes resumed their traditional liberalism, calling for the restoration of parliamentary democracy - as clearly expressed by the example of Cadernos Brasileiros in its interpretation of militarism in I 966.

The closure of the periodical in I970, caused by a lack of funding, testified to the difficulties of implanting the international project in Brazil. Nonetheless, the intellectuals involved benefitted from their experience in the journal. During all its phases, an implicit pact operated: Cadernos Brasileiros would reproduce the international ideology, but ultimately it had the autonomy to decide how to adapt this ideology to domestic issues. It tried to negotiated with and persuade the international directorate about its positions, while also making concessions. This initially allowed it to absorb the impact of the 1962 intervention by simply changing its editor and later make adjustments in response to the I 964 coup and the continuation of the military in power. The intellectuals involved in the journal - not only its directors, but the collaborators too - enjoyed a freedom of expression in the space that it provided for more than ten years, not as puppets manipulated from abroad, nor as useful idiots, but as active protagonists of the cultural and political scene.

Received on 20/7/20I7 | Revised on I/IO/20I7 | Approved on I/II/20I7

Marcelo Ridenti is Full Professor in Sociology at the Institute of Philosophy and Human Sciences of Campinas State University (UNICAMP). He has a $\mathrm{PhD}$ in Sociology from the University of São Paulo and has published various books, including Brasilidade revolucionária: um século de cultura e política (2010), Em busca do povo brasileiro: artistas da revolução, do CPC à era da TV ( $2^{\text {nd }}$ ed., 20I4), and O fantasma da revolução brasileira ( $2^{\text {nd }}$ ed., 20IO). 


\section{NOTES}

I This article results from ongoing research on the cultural Cold War, supported by CNPq. It is based on a bibliography and documents compiled during my stay as visiting professor at Columbia University (Ruth Cardoso Chair, 20I420I5), with funding from the Fulbright Foundation, CAPES and FAPESP. I thank all these agencies, as well as the comments and suggestions from the anonymous reviewers of Sociologia \& Antropologia. A draft version of the article was presented at the International Seminar "A atualidade da periferia no pensamento social", Postgraduate Program in Sociology of the Institute of Philosophy and Human Sciences of Campinas State University (IFCH/ Unicamp), August 20I5. A modified version will be included in the collection resulting from this seminar, edited by Mariana Chaguri and Mário Augusto Medeiros da Silva.

2 On the CCF, see the works of Lasch (I968), Coleman (I989), Gremion (I995), Saunders (2008) [I999], Iber (20II, 20I5), among others.

3 The ample and detailed documentation of the CCF is classified in the "International Association for Cultural Freedom Records, I94I-I978" (IACFR), available at the University of Chicago library.

4 See, for instance the Report to the CCF, Rio de Janeiro, 26 June I964. IACFR, Series II, Box 89, Folder 6. See also the letter (in English) from Barretto to Hunt. Rio de Janeiro, 30 June I966. IACFR, Series II, Box 89, Folder 8.

5 As well as the eight academics on the board, the director Afrânio Coutinho would become a member of the ABL in I962, and Nélida Piñon in I989. Some of the most prestigious names on the board were never members of the ABL, however, including Anísio Teixeira, Érico Veríssimo and Gilberto Freyre. None of these three wrote in the journal, but they maintained good relations with the CCF.

6 Interview with Vicente Barretto by Marcelo Ridenti, Rio de Janeiro, $24^{\text {th }}$ February 20I6. Elizabeth Cancelli (2012: 74) discovered correspondence that attests to "the approach made by the CCF Secretariat in Paris to Mário Pedrosa as early as I954".

7 Letter (in French) from Baciu to Nabokov. Rio de Janeiro, I2 August I962. IACFR, Series II, Box 89, Folder 3. 
8 Letter (in Portuguese) from Baciu to Coutinho, Rio de Janeiro, Io August 1962. IACFR, Series II, Box 89, Folder 3.

9 Luis Mercier Vega was a Belgian anarchist who had fought against Franco in the Spanish civil war, a member of the famous Durruti column. Unlike other collaborators with the CCF, Mercier did not disown his left-wing origins and considered himself an anarchist until his death in I977, and is celebrated even todayby libertarians. See <http://www.atelierdecreationlibertaire.com/Presence-de-LouisMercier.html>.

Io In the interview cited earlier, Barreto also recounted that Afrânio Coutinho, a friend of his father, "a writer like dad, from his generation, is theonewhogotmeajobas thejournal's secretary." However, it was Botsford, also a writer and editor, who taught him the secrets of the trade.

I I Letter (in English) from Hunt to Coutinho. Paris, 2 I April I964. IACFR, Series II, Box 89, Folder 6.

I2 Letter (in English) from Hunt to Coutinho. Paris, I I May I964. IACFR, Series II, Box 89, Folder 6.

I3 Letter (in English) from Coutinho to Hunt. Rio de Janeiro, 30 April I964. IACFR, Series II, Box 89, Folder 6.

I4 Letter (in Portuguese) from Barretto to Mercier. Rio deJaneiro, 20 April I964. IACFR, Series II, Box 559, Folder I7.

I5 Letter (in French) from Mercier to Barretto. Santiago, Chile, 25 April I964. IACFR, Series II, Box 559, Folder 17.

I6 Letter (in Portuguese) from Barretto to Mercier. Rio deJaneiro, 7 May I964. IACFR, Series II, Box 559, Folder I7.

I7 "Direito à heresia." Cadernos Brasileiros n. 24, May-June I964, p. 4.

I8 Letter (in French) from Mercier to Barretto. Mexico, 30 July I964. IACFR, Series II, Box 559, Folder I7.

I9 Letter (in English) from Coutinho to Hunt. Rio de Janeiro, 30 April I964. IACFR, Series II, Box 89, Folder 6.

20 Letter (in English) from Hunt to Coutinho. Paris, I5 May I 964. IACFR, Series II, Box 89, Folder 6.

2I All I9 articles and reviews in this issue discuss the theme of the military from diverse points of view. Cadernos Brasileiros n. 39, Nov/Dec 1966.

22 Interview with Vicente Barretto by Marcelo Ridenti, Rio de Janeiro, 24 February 2016. 
23 Letter (in Portuguese) from Barretto to Mercier. Rio de Janeiro, 27 February I967. IACFR, Series II, Box 56, Folder 2.

24 Letter (in English, handwritten) from Coutinho to Hunt. New York, I3 March 1967. IACFR, Series II, Box 89, Folder 8.

25 Letter (in English) from Barretto to Hunt. Rio de Janeiro, 30 June I966. IACFR, Series II, Box 89, Folder 8.

26 Mundo Nuevo, n. I5, September I967.

27 IACFR, Series II, Box 448, Folder 9 and Box 449, Folder I. Part of the material presented at the event later gave rise to the book edited by Lipset and Solari (1967).

28 Kátia Valladares - whose name appears as assistant editor of Cadernos Brasileiros in I968 - went to Cuba after the I964 coup, accompanied by her husband, the black sailor Marcos Antônio da Silva Lima. Hereturned to Brazil clandestinely and was killed in 1970 as an activist in the Brazilian Revolutionary Communist Party (PCBR). The assistant editor was the daughter of Érica Odebrecht Valladares - a member of the family owning the Odebrecht company - and Clarival do Prado Valadares, a prestigious art critic, responsible for the Goeldi gallery and an active member of the journal's command at least from I965. He invited his daughter to join Cadernos Brasileiros as soon as she came back from Cuba, a legal return negotiated with the authorities. This appointment received the approval of the national and international directors, particularly Luis Mercier. Interview with Kátia do Prado Valladares by Marcelo Ridenti, Rio de Janeiro, 4 September 2017.

29 The Latin American Institute of International Relations (ILARI) was created in 1965, the CCF body for Latin America. ILARI was directed by Luis Mercier Vega (Cancelli 2012: 75).

30 Letter (in French) from Coutinho to Mercier. Rio de Janeiro, 8 October I970. IACFR, Series II, Box 560, Folder 5.

\section{BIBLIOGRAPHY}

Aron, Raymond. (2010). Mémoires. Édition intégrale inédite. Paris: Édition Robert Laffont.

Berghe, Kristine Vanden. (I997). Intelectuales y anticomunismo - la revista Cuadernos Brasileiros (I959-1970). Louvain: Leuven University Press. 
Berghe, Kristine Vanden. (I999). El Congresso por la Libertad de la Cultura y la América Latina. Estudos Ibero-Americanos, PUCRS, XXV/I, p. 217-234.

Cancelli, Elizabeth. (2012). O Brasil e os outros. Porto Alegre: EDIPUCRS.

Coleman, Peter. (1989). The liberal conspiracy: The Congress for Cultural Freedom and the struggle for the mind of postwar Europe. New York: The Free Press/MacMillan.

Czajka, Rodrigo. (2009). Praticando delitos, formando opinião: intelectuais, comunismo e repressão no Brasil (I958-I968). PhD Thesis. PPGS/Universidade Estadual de Campinas.

Gremion, Pierre. (1995). Intelligence de l'anticommunisme. Le Congrès pour la Liberté de la Culture à Paris - I950-I975. Paris: Fayard.

Hook, Sidney. (1953). Heresy, yes - conspiracy, no. New York: The John Day Company.

Iber, Patrick J. (20II). The imperialism of liberty: intellectuals and the politics of culture in Cold War Latin America. PhD Thesis. Department of History/University of Chicago.

Iber, Patrick J. (20I5). Neither peace nor freedom: the cultural Cold War in Latin America. Cambridge: Harvard University Press.

Lasch, Christopher. (I968). The cultural Cold War: a short history of the Congress for Cultural Freedom. In: Towards a new past. Dissenting essays in American History. Nova York: Pantheon Books, p. 322-359.

Lipset, Seymor M. \& Solari, Aldo E. (eds.). (I967). Elites y desarollo en América Latina. Buenos Aires: Paidós.

Ribeiro, Ricardo Alaggio. (2006). A Aliança para o Progresso $e$ as relações Brasil-Estados Unidos. PhD Thesis. PPGCP/Universidade Estadual de Campinas.

Saes, Décio. (1984). Classe média e sistema político no Brasil. São Paulo: T. A. Queiroz.

Saunders, Frances S. (2008). Quem pagou a conta? Rio de Janeiro: Record.

Schwarz, Roberto. (I970). Remarques sur la culture et la politique au Brésil, I964-I969. Les Temps Modernes, 288, Juillet, Paris, p. 37-73. 
Palavras-chave

Cadernos Brasileiros; Congresso pela Liberdade

da Cultura;

intelectuais;

anticomunismo;

golpe de ig64.
Keywords

Cadernos Brasileiros; Congress for Cultural Freedom; intellectuals; anticommunism; I 964 military coup.

\section{A REVISTA CADERNOS BRASILEIROS E O CONGRESSO PELA LIBERDADE DA CULTURA, 1959-1970} Resumo

O artigo propõe reconstituir e analisar as ligações entre a revista Cadernos Brasileiros e o Congresso pela Liberdade da Cultura, que foram ao mesmo tempo de dependência e relativa autonomia, entre 1959 e I970. As duas entidades nem sempre coincidiram plenamente - embora se reivindicassem como liberais e anticomunistas - diante de acontecimentos históricos decisivos do período, como o golpe de I964, a colaboração com o regime militar e a resistência a ele. Os intelectuais envolvidos com Cadernos Brasileiros foram sujeitos nesse processo de lutas sociais, indo de posições anticomunistas tradicionais, favoráveis à "revolução de I964", até a posterior formulação de críticas ao regime militar, abrindo o periódico para a colaboração de cientistas sociais considerados de esquerda, mas sem perder as oportunidades de acomodação com os donos do poder.

\section{THE JOURNAL CADERNOS BRASILEIROS AND THE CONGRESS FOR CULTURAL FREEDOM, 1959-1970}

\section{Abstract}

The article reconstructs and analyses the links between the journal Cadernos Brasileiros and the Congress for Cultural Freedom, which involved a relation of both dependency and relative autonomy, between 1959 and I970. Despite both institutions claiming to be liberal and anti-communist, they did not always fully coincide in their response to decisive historical events of the period, such as the I964 military coup in Brazil, collaboration with the military regime and resistance to it. The intellectuals involved with the Brazilian journal were active in the ongoing social struggles, shifting from strong anti-communist positions, favourable to what they called the 'I 964 revolution,' to the later formulation of criticism of the military regime, opening up the journal to collaboration of social scientists considered left-wing, without losing the opportunity to accommodate the demands of the regime in power. 